\title{
The Actin Cytoskeleton at the Immunological Synapse of Dendritic Cells
}

\author{
José Luis Rodríguez-Fernández* and Olga Criado-García \\ Department of Cellular and Molecular Biology, Centro de Investigaciones Biológicas Margarita Salas, Consejo Superior \\ de Investigaciones Cientificas, Madrid, Spain
}

Dendritic cells (DCs) are considered the most potent antigen-presenting cells. DCs control the activation of T cells (TCs) in the lymph nodes. This process involves forming a specialized superstructure at the DC-TC contact zone called the immunological synapse (IS). For the sake of clarity, we call IS(DC) and IS(TC) the DC and TC sides of the IS, respectively. The IS(DC) and IS(TC) seem to organize as multicentric signaling hubs consisting of surface proteins, including adhesion and costimulatory molecules, associated with cytoplasmic components, which comprise cytoskeletal proteins and signaling molecules. Most of the studies on the IS have focused on the IS(TC), and the information on the IS(DC) is still sparse. However, the data available suggest that both IS

OPEN ACCESS

Edited by:

Noa B. Martin-Cofreces, Princess Royal University Hospital,

Spain

Reviewed by: Lidija Radenovic,

University of Belgrade, Serbia Vincenzo Di Bartolo, Institut Pasteur, France

${ }^{*}$ Correspondence: José Luis Rodríguez-Fernández rodrifer@cib.csic.es

Specialty section:

This article was submitted to Cell Adhesion and Migration, a section of the journal Frontiers in Cell and Developmental Biology

Received: 11 March 2021

Accepted: 05 July 2021

Published: 02 August 2021

Citation:

Rodríguez-Fernández $\mathrm{JL}$ and Criado-García O (2021) The Actin Cytoskeleton at the Immunological

Synapse of Dendritic Cells.

Front. Cell Dev. Biol. 9:679500. doi: 10.3389/fcell.2021.679500 sides are involved in the control of TC activation. The IS(DC) may govern activities of DCs that confer them the ability to activate the TCs. One key component of the IS(DC) is the actin cytoskeleton. Herein, we discuss experimental data that support the concept that actin polarized at the IS(DC) is essential to maintaining IS stability necessary to induce TC activation.

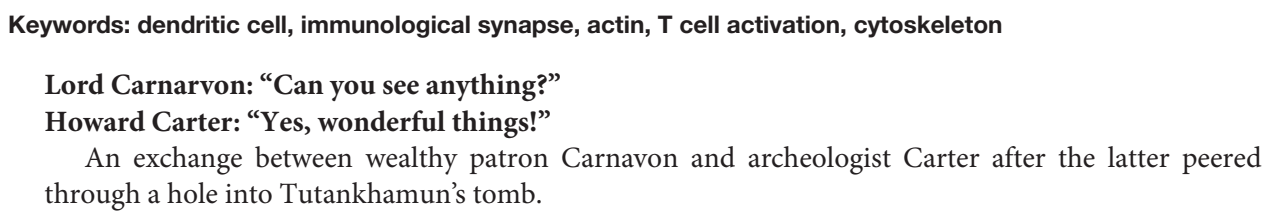

\section{INTRODUCTION}

Dendritic cells (DCs) are the most potent antigen-presenting cells (APCs; Banchereau and Steinman, 1998). There are two main groups of DCs: conventional and plasmacytoid (Banchereau and Steinman, 1998; Merad et al., 2013). DCs are found in tissues in the immature differentiation stage. In the presence of pathogens, they undergo a process of differentiation called maturation, which involves multiple phenotypical changes, including the upregulation of major histocompatibility complex class I (MHC-I) and class II (MHC-II) and costimulatory molecules, like CD80 and CD86. Mature DCs migrate to the lymph nodes (LNs), where they present pathogen-derived peptides via MHC-I to $\mathrm{CD}^{+} \mathrm{T}$ cells (TCs) or via MHC-II to $\mathrm{CD}^{+}$TCs, resulting in the activation of these lymphocytes. Hereafter, unless otherwise indicated, when we use the word DCs, we refer to the conventional mature DCs. Several studies have shown that activation of naive TCs in the LNs involves, first, brief serial DC-TC encounters, which are antigen independent, followed by prolonged and stable antigen-dependent contacts that last several hours (Delon et al., 1998; Iezzi et al., 1998; 
Stoll et al., 2002; Bajenoff et al., 2003; Bousso and Robey, 2003; Mempel et al., 2004; Miller et al., 2004; Shakhar et al., 2005; Celli et al., 2007). Finally, the TCs recover their motility and proliferate (Mempel et al., 2004; Celli et al., 2007; Scholer et al., 2008). The region of tight adhesion that connects DCs and TCs when they establish stable interactions is called the immunological synapse (IS). We call the DC and TC sides of the IS the IS(DC) and IS(TC), respectively. Most studies on the IS have centered on the IS(TC), and analyses of the IS(DC) are sparse (Riol-Blanco et al., 2009; Rodriguez-Fernandez et al., 2010a,b; Benvenuti, 2016; Verboogen et al., 2016; Gomez-Cabanas et al., 2019; Alcaraz-Serna et al., 2021). Herein, we analyze the role of the filamentous-actin (Factin) cytoskeleton of the IS(DC) in TC activation.

\section{ORGANIZATION OF THE PLASMA MEMBRANE PROTEINS COMPONENTS OF THE IS(DC)}

The first studies on the IS focused on the IS(TC) (Monks et al., 1998; Grakoui et al., 1999). In one of the experimental models used, the $\mathrm{CD}^{+}$TCs were plated on a glass-supported lipid bilayer that was converted into a surrogate APC by inserting the intercellular adhesion molecule 1 (ICAM-1), the ligand of the integrin lymphocyte function-associated antigen (LFA-1), and peptides bound to MHC (pMHC; Grakoui et al., 1999). In another model, the $\mathrm{CD}^{+}{ }^{+}$TCs were allowed to form IS with B cells (BCs; Monks et al., 1998; Grakoui et al., 1999). Following the binding of the TCs either to the glass-supported lipid bilayer or to the BCs, the costimulatory molecule CD28 and the TC receptor (TCR) clustered together in a region called the central supramolecular activation cluster (cSMAC). Contiguous to this region are found LFA-1 molecules that form a ring called peripheral SMAC (pSMAC). Large negatively charged molecules like CD43 and CD45 organize in an outermost ring called distal SMAC (dSMAC; Monks et al., 1998; Grakoui et al., 1999; Freiberg et al., 2002). Interestingly, when the DCs form the IS with TCs (naïve or activated) at the IS(TC), instead of the monocentric organization described above, surface proteins form multiple protein clusters that include TCRs, adhesion proteins, and costimulatory molecules (Brossard et al., 2005; Rothoeft et al., 2006; Reichardt et al., 2007; Fisher et al., 2008; Tseng et al., 2008; Thauland and Parker, 2010). The ability of the DCs to promote multicentric IS(TC) could contribute to explain why they are such potent APCs. Numerous clusters of CD3 and costimulatory molecules multiply the signaling from these receptors, resulting in robust TC activation (Leithner et al., 2021). Supporting this concept, TCs plated on surrogate-patterned APCs that promote TCR or CD28 clusters show enhanced functionality (Mossman et al., 2005; Shen et al., 2008).

\section{POLARIZATION OF F-ACTIN AT THE IS(DC)}

The following examples, in which fixed cells were stained with phalloidin, show that F-actin polarizes in the IS(DC) upon allogeneic or antigen-specific DC-TC formation. Allogenic conjugates include (i) bone marrow-derived DCs (BM-DCs) (BALB/c genetic background) and $\mathrm{CD} 4^{+}$TCs $(\mathrm{C} 57 \mathrm{BL} / 6$ genetic background) (Al-Alwan et al., 2001b) and (ii) human monocytederived DCs and allogeneic lymphoblasts (Riol-Blanco et al., 2009). Antigen-specific conjugates include (i) OVA peptideloaded BM-DC, from $\mathrm{BALB} / \mathrm{c}$ or $\mathrm{C} 57 \mathrm{BL} / 6$ mice, and $\mathrm{DO} 11.10$ or OTII CD4 ${ }^{+}$TCs, respectively (Al-Alwan et al., 2003; Eun et al., 2006; Riol-Blanco et al., 2009), and (ii) OVA peptideloaded BM-DCs and OTI CD8 ${ }^{+}$TCs (Tanizaki et al., 2010). A drawback of these fluorescence microscopy analyses performed with fixed conjugates is that it is difficult to know for certain whether the phalloidin-stained F-actin belongs to the IS(TC) or the IS(DC). However, recently, the use of Lifeact, an amino acid fragment of the protein ABP140 that binds selectively to F-actin, has solved this problem (Riedl et al., 2008; Leithner et al., 2021). High-resolution confocal microscopy analysis of Lifeact-green fluorescent protein (Lifeact-GFP)-expressing DCs that form IS with OTII CD4 ${ }^{+}$TCs shows that F-actin displays at the IS(DC) a multifocal organization, with foci of different sizes separated by regions where actin is sparse (Leithner et al., 2021). Finally, fluorescence recovery after photobleaching (FRAP) experiments performed with mCherry-labeled actin-transfected BM-DCs that interact with OTII TCs showed a slower recovery at the IS(DC) compared with the cortex, suggesting a higher stability and specific molecular features of the F-actin network at the IS(DC) (Malinova et al., 2016).

\section{SURFACE PROTEINS THAT INDUCE ACTIN ACCUMULATION IN THE IS(DC)}

Engagement of MHC-II, MHC-I, or LFA-1 with specific antibodies bound to polystyrene beads induces F-actin accumulation only in DCs that bind to beads associated with anti-MHC-II antibodies (Al-Alwan et al., 2003). The lack of effect of MHC-I was unexpected because F-actin accumulates at the IS(DC) in DC-OTI $\mathrm{CD}^{+}$TC conjugates (Tanizaki et al., 2010). Moreover, engagement of MHC-I on the membrane of endothelial cells with antibodies induces activation of the F-actin regulator ras homolog family member A (RhoA) (Coupel et al., 2004; Lepin et al., 2004) and actin organization (Lepin et al., 2004; Jin et al., 2007; Ziegler et al., 2012a,b). Hence, other experimental strategies, including different anti-MHC-I antibodies, should be used before ruling out that MHC-I controls F-actin accumulation in DCs. An analysis of wild-type (WT)-BM-DCs or CD80/86 knock-out (KO)-BM-DCs interacting with DO11.10 CD4 + TCs suggests that $\mathrm{CD} 80 / \mathrm{CD} 86$ induces actin polarization at the IS(DC) (Rothoeft et al., 2006). However, actin failed to accumulate at the IS(DC) upon engagement of CD86 on DCs with antibodies or when BM-DCs, expressing that the $\mathrm{CD} 28$ receptors CD80 and CD86 interact with human Jurkat cells expressing murine CD28 (Al-Alwan et al., 2003; Rothoeft et al., 2006). Therefore, stimulation of CD80 or CD86 is not sufficient to promote F-actin aggregation. Finally, the semaphorin receptor Plexin-A1, which is localized at the IS(DC), can also induce RhoA activation and F-actin polarization in this region (Eun et al., 2006). 


\section{ROLE OF F-ACTIN AND \\ ACTIN-REGULATORY PROTEINS AT THE IS(DC) ON TC ACTIVATION}

Below, we analyze reports that provide information on the role of DC's F-actin and actin-regulatory proteins on TC activation (Figure $\mathbf{1}$ and Table 1). When analyzing these experimental data, it is important to take into consideration several points. First, the focus of most of the studies available on this issue was not the IS(DC). Second, the proteins analyzed can be expressed in the IS(DC) and elsewhere in DCs, like the DCs' cortex (e.g., F-actin, WRC, WASP, and Myo9b), implying that these proteins may exert their regulatory effects inside and/or outside the IS(DC) (e.g., WASP, Rac1/2, and mDia also regulate migration). Third, actin-regulatory proteins can also govern actin-independent functions (e.g., HS1). Fourth, the experimental strategies employed to study the role of these molecules, namely, the use of pharmacological agents to inhibit F-actin or DCs deficient in actin-regulatory proteins, do not discriminate between the IS(DC) and other intracellular regions.

\section{Filamentous Actin}

To analyze the role of F-actin at the IS(DC), pharmacological agents have been used that alter actin stability, including cytochalasin $\mathrm{D}$, latrunculin $\mathrm{A}$, and mycalolide $\mathrm{B}(\mathrm{MycB})$, which disrupt F-actin, and Jasplakinolide, which stabilizes it (Fenteany and Zhu, 2003). When DCs treated with any of these inhibitors interact with DO11.10 or OTII CD4 ${ }^{+}$TCs, the activation and proliferation of these lymphocytes is inhibited (Al-Alwan et al., 2001b; Leithner et al., 2021; Table 1). These results emphasize the importance of the integrity of the DCs' actin cytoskeleton for TC activation (Al-Alwan et al., 2001b; Leithner et al., 2021). Confocal microscopic analyses of DCs that interact with LifeactGFP expressing OTII CD4 ${ }^{+}$TCs show that IS(TC) form multiple actin foci (Leithner et al., 2021). However, when DCs pretreated with $\mathrm{MycB}$ to disrupt F-actin were allowed to interact with the Lifeact-GFP OTII CD4 ${ }^{+}$TCs, $\sim 50 \%$ of the IS(TC) present a ring of F-actin surrounding an actin-free circle, instead of a multifocal actin organization (Leithner et al., 2021; Table 1). Hence, multifocal actin at the IS(DC) contributes partially to stabilizing multifocal actin at the IS(DC) and predictably also to

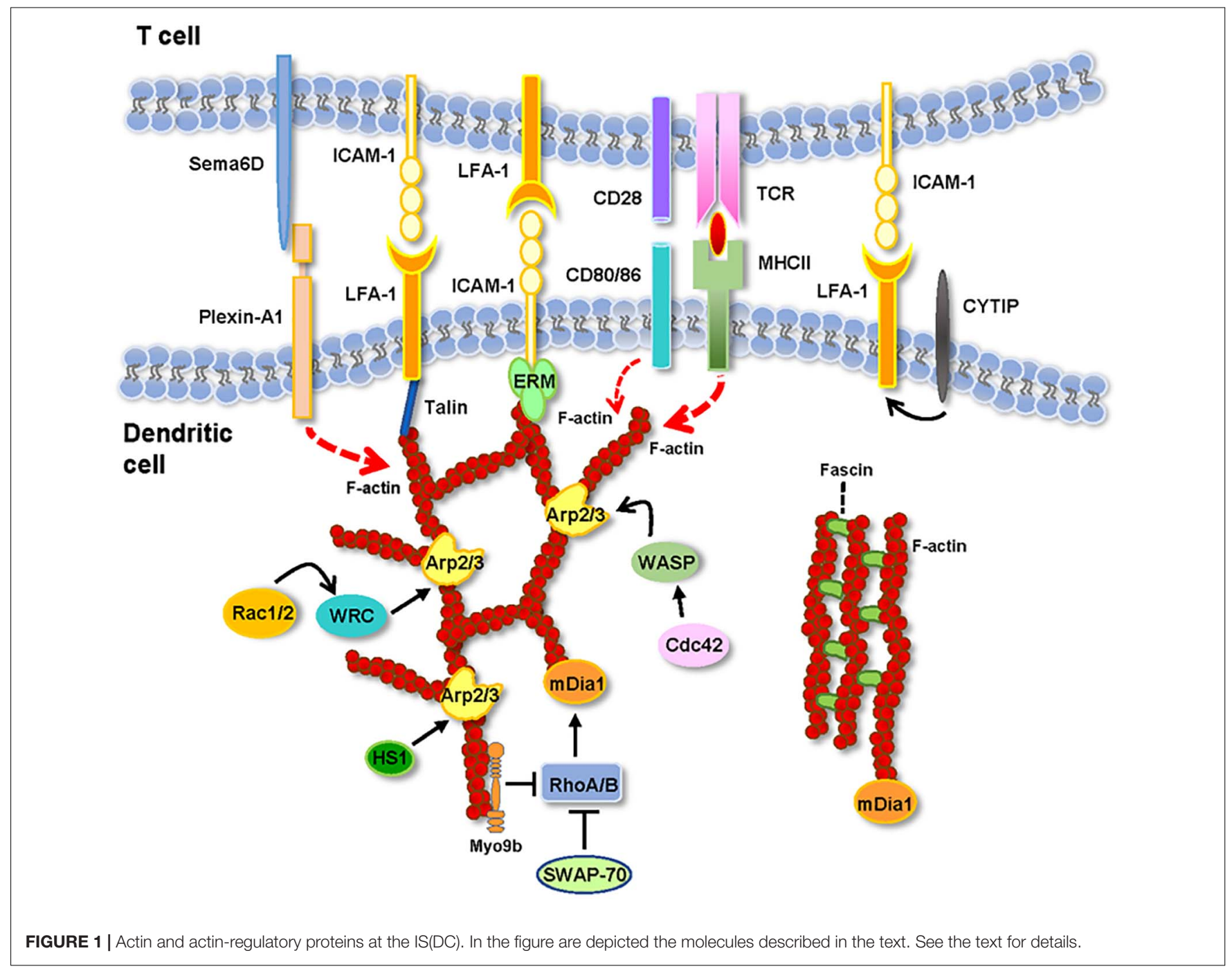


TABLE 1 | Effects of the perturbation of F-actin and actin-regulatory molecules in the DCs. In the table are presented the effects observed following the interaction between TCs and either pharmacologically inhibited or KO-DCs, which are compared with the results obtained with TCs that interact with uninhibited or WT-DCs controls.

\begin{tabular}{|c|c|c|c|c|c|c|c|}
\hline \multirow[t]{2}{*}{ DC protein } & \multirow[t]{2}{*}{$\begin{array}{l}\text { Role of the target } \\
\text { protein in the DCs }\end{array}$} & \multirow[t]{2}{*}{\begin{tabular}{|c|} 
Tool used to inhibit the \\
target protein in the DCs
\end{tabular}} & \multicolumn{2}{|c|}{ Type of the IS formed } & \multicolumn{2}{|c|}{$\begin{array}{l}\text { Effect of inhibition of the DC target } \\
\text { after inducing IS formation }\end{array}$} & \multirow[t]{2}{*}{ References } \\
\hline & & & $\begin{array}{l}\text { Antigen-specific } \\
\text { (interacting cells) }\end{array}$ & Allogeneic (interacting cells) & $\begin{array}{c}\text { TC activation and/or } \\
\text { proliferation }\end{array}$ & Other effects in the TCs or DCs & \\
\hline \multirow[t]{2}{*}{ F-Actin } & \multirow[t]{2}{*}{$\begin{array}{l}\text { Cytoskeletal } \\
\text { protein }\end{array}$} & $\begin{array}{l}\text { Cytochalasin D } \\
\text { Jasplakinolide } \\
\text { Latrunculin A }\end{array}$ & $\begin{array}{c}\text { Inhibited } \\
\text { BM-DCs } \\
\text { (BALB/C) and } \\
\text { DO11.10 CD4 } \\
\text { TCs } \\
\text { Inhibited } \\
\text { BM-DCs } \\
\text { (C57BL/6) and } \\
\text { OTII CD4 } 4^{+} \text {TCs }\end{array}$ & $\begin{array}{l}\text { Inhibited } \\
\text { BM-DCs } \\
\text { (BALB/C) and } \\
\text { CD4 }{ }^{+} \mathrm{TCs} \\
\text { (C57BL/6) }\end{array}$ & Reduced & $\begin{array}{c}\text {-Reduced production of IL-2 in the DO11.10 and } \\
\text { OTII CD4+ TCs }\end{array}$ & $\begin{array}{l}\text { Al-Alwan et al., } \\
\text { 2001b }\end{array}$ \\
\hline & & Mycalolide B & $\begin{array}{l}\text { Inhibited } \\
\text { BM-DCs and } \\
\text { OTII CD4+ TCs } \\
\text { Inhibited } \\
\text { Lifeact-GFP } \\
\text { BM-DCs and } \\
\text { OTII CD4 } 4^{+} \text {TCs }\end{array}$ & & Reduced & $\begin{array}{l}\text {-Reduction (-50\%) in the number of IS(TC) that } \\
\text { display multifocal actin organization } \\
\text {-Inhibition of early activation markers CD62L and } \\
\text { CD69 and IL-2 production in the OTII CD4 } 4^{+} \text {TCs }\end{array}$ & $\begin{array}{l}\text { Leithner et al., } \\
\quad 2021\end{array}$ \\
\hline \multirow[t]{4}{*}{ WASP } & \multirow[t]{4}{*}{$\begin{array}{c}\text { Arp2/3 } \\
\text { nucleation-promoting } \\
\text { factor }\end{array}$} & WASP-KO BM-DCs & $\begin{array}{l}\text { WASP-KO BM-DCs and } \\
\text { OTII CD4 } 4^{+} \text {TCs }\end{array}$ & & Reduced & $\begin{array}{l}\text {-WASP-KO DCs are less motile } \\
\text {-Unstable IS } \\
\text {-Altered signaling at the IS(TC) } \\
\text { - Inhibition IL-2 production in the activated OTII } \\
\text { CD4+ TC }\end{array}$ & \multirow{3}{*}{$\begin{array}{l}\text { Bouma et al., } \\
2011\end{array}$} \\
\hline & & WASP-Y293F BM-DCs & $\begin{array}{c}\text { WASP Y293F } \\
\text { BM-DCs and OTII } \\
\text { CD4 } 4^{+} \text {TCs }\end{array}$ & & Reduced & $\begin{array}{l}\text {-Reduction in IS formation and priming ability } \\
\text {-Inhibition IL-2 production in the activated OTII } \\
\text { CD4+ TCs }\end{array}$ & \\
\hline & & $\begin{array}{c}\text { Human WASP-/-BM-CD34+ } \\
\text { DCs }\end{array}$ & & $\begin{array}{c}\text { Human WASP-/-BM-CD34+ DCs and } \\
\text { human PBMCs }\end{array}$ & Reduced & $\begin{array}{l}\text {-Reduced production of interferon- } \gamma \text { (IFN- } \gamma \text { ) } \\
\text { in the TCs }\end{array}$ & \\
\hline & & WASP-KO BM-DCs & $\begin{array}{l}\text { WASP-KO BM-DCs and } \\
\text { OTI CD8 } 8^{+} \text {TCs }\end{array}$ & & Reduced & $\begin{array}{l}\text {-Reduced duration of DC and CD8 } 8^{+} \mathrm{TC} \text { contacts } \\
\text {-Reduced levels of CD69 in the OTI CD8 } 8^{+} \text {TCs } \\
\text {-Reduced cross-presentation in vivo }\end{array}$ & $\begin{array}{l}\text { Pulecio et al., } \\
2008\end{array}$ \\
\hline \multirow[t]{2}{*}{ HS1 } & \multirow[t]{2}{*}{$\begin{array}{l}\text { Arp2/3 } \\
\text { nucleation- } \\
\text { promoting } \\
\text { factor }\end{array}$} & $\begin{array}{l}\text { HS1-KO } \\
\text { BM-DCs } \\
\text { (BALB/C) }\end{array}$ & $\begin{array}{l}\text { HS1-KO } \\
\text { BM-DCs and } \\
\text { DO11.10 CD4 } \\
\text { TCs }\end{array}$ & & \multirow[t]{2}{*}{ Reduced } & \multirow[t]{2}{*}{$\begin{array}{l}\text {-Maturation, pinocytosis, and phagocytosis, not } \\
\text { affected in the HS1-KO DCs } \\
\text {-Receptor-mediated endocytosis selectively } \\
\text { reduced in the HS1-KO DCs } \\
\text {-Reduced production of IL-2 in the DO11.10 CD4+ } \\
\text { TCs and OTII CD4+ TCs }\end{array}$} & \multirow[t]{2}{*}{$\begin{array}{l}\text { Huang et al., } \\
2011\end{array}$} \\
\hline & & $\begin{array}{l}\mathrm{HS1-KO} \\
\mathrm{BM}-\mathrm{DCs} \\
\text { (C57BL/6) }\end{array}$ & $\begin{array}{l}\text { HS1-KO BM-DC } \\
\text { and OTII CD4 } 4^{+} \\
\text {TCs }\end{array}$ & & & & \\
\hline WRC & $\begin{array}{c}\text { Arp2/3 } \\
\text { nucleation-promoting } \\
\text { factor }\end{array}$ & WRC-deficient BM-DCs & $\begin{array}{l}\text { WRC-deficient BM-DCs } \\
\text { and OTII CD4+ TCs }\end{array}$ & & Reduced & $\begin{array}{l}\text {-DC-TC contacts last longer -Reduced production } \\
\text { of IL-2 in the OTII CD4 }{ }^{+} \text {TCs. }\end{array}$ & \begin{tabular}{|c} 
Leithner et al., \\
2021
\end{tabular} \\
\hline
\end{tabular}


TABLE 1 | Continued

\begin{tabular}{|c|c|c|c|c|c|c|c|}
\hline \multirow[t]{2}{*}{ DC protein } & \multirow[t]{2}{*}{$\begin{array}{l}\text { Role of the target } \\
\text { protein in the DCs }\end{array}$} & \multirow[t]{2}{*}{\begin{tabular}{|} 
Tool used to inhibit the \\
target protein in the DCs
\end{tabular}} & \multicolumn{2}{|c|}{ Type of the IS formed } & \multicolumn{2}{|r|}{$\begin{array}{l}\text { Effect of inhibition of the DC target } \\
\text { after inducing IS formation }\end{array}$} & \multirow[t]{2}{*}{ References } \\
\hline & & & $\begin{array}{l}\text { Antigen-specific } \\
\text { (interacting cells) }\end{array}$ & Allogeneic (interacting cells) & $\begin{array}{c}\text { TC activation and/or } \\
\text { proliferation }\end{array}$ & Other effects in the TCs or DCs & \\
\hline \multirow[t]{2}{*}{ mDia } & \multirow[t]{2}{*}{$\begin{array}{l}\text { Actin } \\
\text { nucleation } \\
\text { factor }\end{array}$} & $\begin{array}{l}\text { mDia-KO } \\
\text { BM-DCs }\end{array}$ & & $\begin{array}{c}\text { mDia-KO BM-DCs } \\
\text { (C57BL/6) and CD4 }{ }^{+} \\
\text {TCs (BALB/c) }\end{array}$ & Reduced & -Reduced production of IFN- $\gamma$ in the $\mathrm{CD} 4^{+} \mathrm{TCs}$ & \multirow[t]{2}{*}{\begin{tabular}{|l} 
Tanizaki et al., \\
2010
\end{tabular}} \\
\hline & & $\begin{array}{l}\text { mDia-KO } \\
\text { BM-DCs }\end{array}$ & $\begin{array}{l}\text { mDia-KO } \\
\text { BM-DCs and } \\
\text { OTII CD4+ TCs } \\
\text { mDia-KO } \\
\text { BM-DCs and } \\
\text { OTI CD8 } 8^{+} \text {TCs }\end{array}$ & & Reduced & $\begin{array}{l}\text {-Shorter duration contacts between DCs and OTII } \\
\text { CD } 4^{+} \text {or OTI CD8 } 8^{+} \text {TCs } \\
\text {-Lower levels of IFN- } \gamma \text { in the TCs }\end{array}$ & \\
\hline Fascin & Actin bundling protein & $\begin{array}{l}\text { Fascin antisense } \\
\text { oligonucleotides }\end{array}$ & & $\begin{array}{l}\text { Inhibited BM-DCs } \\
\text { (BALB/c) and TCs } \\
\text { (C57BL/6) }\end{array}$ & Reduced & $\begin{array}{l}\text {-Fascin antisense-treated BM-DCs present fewer } \\
\text { and smaller dendrites but not changes in MHC-II } \\
\text { or costimulatory CD86 molecules }\end{array}$ & $\begin{array}{l}\text { Al-Alwan et al., } \\
\text { 2001a }\end{array}$ \\
\hline SWAP-70 & $\begin{array}{c}\text { Rac-GEF* } \\
\text { Actin bundling } \\
\text { protein }\end{array}$ & $\begin{array}{l}\text { SWAP-70-KO } \\
\text { BM-DCs }\end{array}$ & $\begin{array}{l}\text { SWAP-70-KO } \\
\text { BM-DCs and TC } \\
\text { hybridoma } \\
\text { (BO97.10) } \\
\text { SWAP-70-KO } \\
\text { SPDCs and TC } \\
\text { hybridoma } \\
(1 \mathrm{H} 3.1)\end{array}$ & & Reduced & $\begin{array}{c}\text { - Total levels of MHC-II are not altered, however, its } \\
\text { location is reduced in the SWAP-70-KO DCs } \\
\text {-SWAP-70-KO DCs display lower F-actin density } \\
\text { at the IS(DC) } \\
\text {-WT and SWAP-70 DCs show similar migration } \\
\text {-Reduced production of IL-2 } \\
\text { in TC hybridomas }\end{array}$ & $\begin{array}{l}\text { Regnault et al., } \\
\text { 1999; Blander } \\
\text { and Medzhitov, } \\
\text { 2006; } \\
\text { Ocana-Morgner } \\
\text { et al., } 2009\end{array}$ \\
\hline Myo9b & Rho-GAP* & Myo9b-KO BM-DC & $\begin{array}{l}\text { Myo9b-KO BM-DCs and } \\
\text { OTII CD4+ TCs }\end{array}$ & & Reduced & $\begin{array}{l}\text {-Lower number of interactions, which last longer, } \\
\text { between DCs and TCs } \\
\text {-Increased levels of F-actin at the IS(DC) } \\
\text {-Early TC activation marker CD69 inhibited within } \\
\text { 3D-collagen matrices, but not in liquid cultures }\end{array}$ & Xu et al., 2014 \\
\hline Rac1/2 & $\begin{array}{c}\text { Small } \\
\text { GTPases }^{*}\end{array}$ & $\begin{array}{l}\text { Rac1/2-KO } \\
\text { BM-DC }\end{array}$ & $\begin{array}{l}\text { Rac1/2-KO } \\
\text { BM-DCs and } \\
\text { Marilyn CD4+ } \\
\text { TCs }\end{array}$ & & Reduced & $\begin{array}{l}\text {-Brief contacts between } \mathrm{DC} \text { and } \mathrm{CD} 4^{+} \mathrm{TCs} \\
\text {-Inhibition of the early TC activation marker CD69 }\end{array}$ & $\begin{array}{l}\text { Benvenuti } \\
\text { et al., } 2004\end{array}$ \\
\hline \multirow[t]{2}{*}{ CYTIP } & \multirow[t]{2}{*}{$\begin{array}{c}\text { Cytohesin-interacting } \\
\text { protein }\end{array}$} & CYTIP siRNA & $\begin{array}{c}\text { Inhibited Human mono-DCs } \\
\text { and Human } \mathrm{CD}^{+} \mathrm{TCs}\end{array}$ & & Reduced & $\begin{array}{l}\text {-CYTIP siRNA-treated DCs display increased } \\
\text { adhesion onto TCs } \\
\text {-Lower TC activation when siRNA-CYTIP treated } \\
\text { DCs partially loaded with A2.1 restricted EBV } \\
\text { peptide interact with antigen-specific CD8 }{ }^{+} \text {TCs }\end{array}$ & $\begin{array}{l}\text { Hofer et al., } \\
2006\end{array}$ \\
\hline & & CYTIP-KO BM-DC & $\begin{array}{l}\text { CYTIP-KO BM-DCs and } \\
\text { OTII CD4 + TCs } \\
\text { CYTIP-KO BM-DCs and } \\
\text { OTI CD8 + TCs }\end{array}$ & & Increased & $\begin{array}{l}\text {-WT and CYTIP-KO DCs express similar levels of } \\
\text { costimulatory molecules } \\
\text {-Increased proliferation, measured after } 4 \text { days of } \\
\text { culture by }{ }^{3} \mathrm{H} \text {-thymidine incorporation }\end{array}$ & Heib et al., 2012 \\
\hline
\end{tabular}

${ }^{*} A$ short note on the regulation of the small GTPases shown in this table and in Figure 1. These proteins cycle between inactive (GDP-bound) and active (GTP-bound) states, which can interact with effector proteins that relay downstream signaling. This cycle is regulated by specific guanine nucleotide exchange factors (GEFs), which catalyze the release of the bound GDP that is replaced by GTP, and by GTPase-activating proteins (GAPS), which induce GTP hydrolysis. 
the formation of the multicentric IS(TC) (Brossard et al., 2005; Rothoeft et al., 2006; Reichardt et al., 2007; Fisher et al., 2008; Tseng et al., 2008; Thauland and Parker, 2010), although this has to be confirmed in future studies because, in the experiments described, the authors did not stain the surface proteins, such as $\mathrm{CD} 3$, and other molecules, which organize in foci in the IS(TC) (Leithner et al., 2021). Finally, F-actin at the IS(DC) can also control DC-TC adhesion by selectively regulating the lateral mobility on the plasma membrane of ICAM-1 (Comrie et al., 2015). Immobilized ICAM-1 at the IS(DC) can promote LFA-1 activation on the IS(TC) and increase DC-TC adhesion (Feigelson et al., 2010).

\section{Wiskott-Aldrich Syndrome Protein}

Wiskott-Aldrich syndrome protein (WASP) is a nucleationpromoting factor (NPF) that activates the actin-related protein 2/3 (Arp2/3) complex (Figure 1). Arp2/3 is an actin-nucleation factor (ANF) that assembles actin dimers or trimers that serve as nuclei that subsequently polymerize into Y-branched actin networks (Schonichen and Geyer, 2010). WASP organize in foci within the IS(DC) (Leithner et al., 2021). WASP-KO BM-DCs show reduced motility and lower F-actin levels (Bouma et al., 2011; Malinova et al., 2016). WASP-KO BM-DCs that interact with OTII CD4 ${ }^{+}$TCs in vitro present a high number of transient interactions and reduced DC-TC contact areas, suggesting that in the DCs, WASP may stabilize the interactions with the TCs (Bouma et al., 2011; Malinova et al., 2016; Table 1). Similar conclusions have been obtained in in vitro and in vivo studies that analyze the interactions between WASP-KO BM-DCs and OTI CD8 ${ }^{+}$TCs (Pulecio et al., 2008). At the IS(DC) formed by the WASP-KO BM-DCs, the levels of ICAM-1 and MHC-II are reduced (Malinova et al., 2016). The levels of TCR, LFA-1, F-actin, and talins are also reduced at the IS(TC). Moreover, TCRdependent signaling was also altered, resulting in reduced IL-2 production, and TC proliferation (Bouma et al., 2011; Malinova et al., 2016). Further supporting a role for the WASP/Arp $2 / 3$ axis in IS formation, DCs that express Y293F-WASP (a mutation that impairs WASP's ability to activate Arp2/3) display a low number of IS with TCs and reduced priming ability (Bouma et al., 2011). Finally, in FRAP experiments performed with Cherry-labeled actin-transfected WASP-KO, Y293F-WASP, and WT-BM-DCs that formed IS with OTII $\mathrm{CD}^{+}{ }^{+} \mathrm{TCs}$, actin recovery at the IS(DC) was slower in the WT DCs compared with the WASP-KO and Y293F-WASP DCs, suggesting that WASP-Arp2/3-mediated formation of branched actin stabilizes the actin network at the IS(DC) (Malinova et al., 2016).

\section{Hematopoietic Lineage Cell-Specific Protein 1}

Hematopoietic lineage cell-specific protein 1 (HS1) is a NPF that induces Arp2/3-dependent branched actin networks, and, moreover, it can also bind and stabilize this network (Weaver et al., 2001; Uruno et al., 2003; Hao et al., 2005; Dehring et al., 2011; Figure 1). Since HS1 expression increases during DC maturation (Huang et al., 2011), it is interesting to study whether this molecule could regulate actin organization at the IS(DC) and DCs' priming ability (Table 1). WT and HS1-KO BM-DCs bind and present OVA peptides equally as well with DO11.10 CD4 ${ }^{+}$ TCs (Huang et al., 2011). However, HS1-KO BM-DCs loaded with intact OVA protein display a reduced ability to activate the $\mathrm{CD}^{+}$TCs (Huang et al., 2011). WT and HS1-KO BMDCs present the MHC-I-restricted VSV8 peptide equally as well with the $\mathrm{CD}^{+}$TC hybridoma N15. However, when VSV8 was complexed with the protein GRP94, which also uses the MHCI pathway of antigen presentation, the priming ability of the HS1-KO BM-DCs was impaired. It was observed that receptormediated endocytosis was selectively inhibited in the HS1-KO BM-DCs, preventing antigen uptake (Huang et al., 2011). It was also found that HS1 is required for antigen uptake because it participates, together with dynamin 2, in the scission of the endocytic vesicles (Huang et al., 2011). Hence, although HS1 is a NPF, it apparently regulates antigen presentation through the control of antigen endocytosis.

\section{WAVE Regulatory Complex}

WASP-family verprolin homologous proteins (WAVE) regulatory complex (WRC) is an NPF that activates Arp2/3 and induces branched actin (Buracco et al., 2019; Figure 1). WRC is found in the IS(DC), but it also associates with F-actin at the DC cortex (Leithner et al., 2021). Upon interaction of WRC-deficient BM-DCs (Park et al., 2008) with OTII CD4 ${ }^{+}$ TCs, F-actin displays a multifocal organization in the IS(TC), like the IS(TC) formed by the WT BM-DCs (Leithner et al., 2021; Table 1). However, F-actin levels at the IS(DC) are reduced, suggesting that WRC promotes actin accumulation in this region. WRC-deficient DC-TC contacts last longer and display larger areas of contact (Leithner et al., 2021). These prolonged interactions are associated with an increase in the levels of the phospho-ezrin-radixin-moesin (ERM), suggesting a higher anchoring of ICAM-1 to cortical F-actin, which may result in the immobilization of this ligand and increased LFA-1-mediated DCTC adhesion (Comrie et al., 2015; Leithner et al., 2021). These abnormal long-lasting interactions between WRC-deficient DCs and TCs may explain the observed reduction in the activation of the TCs (Leithner et al., 2021).

\section{Mammalian Homolog of Diaphanous}

Mammalian homolog of diaphanous (mDial) is an ANF of the formin family that promotes F-actin elongation (Schonichen and Geyer, 2010; Figure 1). The mDia-KO-BM-DCs display reduced adhesion and impaired migration (Tanizaki et al., 2010). CD4 ${ }^{+}$ TCs that establish alloreactive interactions with mDia-KO BMDC also presented reduced proliferation and low interferon- $\gamma$ (IFN- $\gamma$ ) production (Table 1). Two-photon microscopy analysis shows that mDia-KO BM-DCs that interact with OTII CD4 ${ }^{+}$TCs or with OTI CD8 + TCs establish brief contacts within the LNs, indicating that DCs' $\mathrm{mDia}$ is important for keeping stable ISs (Tanizaki et al., 2010). Hence, correct TC activation requires of mDial expression in the DCs.

\section{Fascin}

Fascin is an actin-bundling protein whose expression is increased during DC maturation (Mosialos et al., 1996; Al-Alwan et al., 2001a; Yamashiro, 2012). In mature DCs, fascin, which can localize to the IS(DC), controls dendrite formation (Al-Alwan 
et al., 2001a,b; Rothoeft et al., 2006; Figure 1). In antigenspecific models of IS formation, accumulation of fascin and F-actin correlates with more extended contacts between DCs and TCs, increased TC proliferation, and CD4 ${ }^{+}$Th1 TC-dependent responses (Rothoeft et al., 2006). Using an allogeneic model of IS formation, it is observed that the levels of fascin in DCs correlate with the ability of these cells to stimulate the TCs (Al-Alwan et al., 2001a; Table 1). Finally, in an alloreactive IS model, it was observed that a reduction of fascin levels in the BM-DCs with antisense oligonucleotides inhibits their ability to allostimulate the TCs (Al-Alwan et al., 2001a). Therefore, fascin-mediated bundling of F-actin in DCs contributes to TC priming.

\section{Switch-Associated Protein $\mathbf{7 0}$}

Switch-associated protein 70 (SWAP-70) is a Rac GEF (see Table 1 and legend) that also controls F-actin bundling (Gomez-Cambronero, 2012; Chacon-Martinez et al., 2013; Figure 1). Although WT and SWAP-70-KO DCs express similar total MHC-II levels, SWAP-70-KO BM-DCs show a reduced expression of MHC-II on the plasma membrane (OcanaMorgner et al., 2009). OVA peptide-loaded SWAP-70-KO DCs' ability to prime TCs is impaired (Ocana-Morgner et al., 2009), as shown by their reduced ability to activate two different MHCII-restricted TC hybridomas (Regnault et al., 1999; Blander and Medzhitov, 2006). In SWAP-70-KO DCs, the actin regulatory GTPases RhoA and RhoB are constitutively activated, resulting in an increase in the amount of F-actin in these cells (OcanaMorgner et al., 2009; Sit and Manser, 2011). Inhibition of RhoA and RhoB in the SWAP-70-KO DCs with Clostridium botulinum increased $\mathrm{MHC}$-II on their plasma membrane and helped recover their ability to activate the TCs. Hence, it is suggested that the high F-actin levels prevent the correct MHC-II localization on the plasma membrane (Bretou et al., 2016). Therefore, SWAP70 may inhibit RhoA and RhoB activation, which prevents an abnormal increase in F-actin and allows MHC-II localization on the membrane of the DCs (Ocana-Morgner et al., 2009).

\section{Myosin IXb}

Myosin IXb (Myo9b) is a cytoskeletal motor that displays Rho-GTPase-activating protein (GAP) activity (see Table $\mathbf{1}$ and legend). Myo9b colocalizes with F-actin in DCs (Hanley et al., 2010; Xu et al., 2014; Figure 1). Compared to WT-BM-DCs, KOMyo9B BM-DCs present a low number interaction with OTII $\mathrm{CD}^{+}$TCs, although these interactions last longer (Xu et al., 2014). F-Actin is highly increased in the IS(DC) of the KOMyo9B BM-DCs that form IS with OTII CD4 ${ }^{+}$TCs. However,

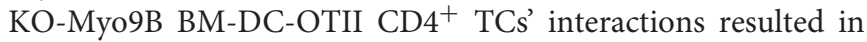
reduced proliferation within $3 \mathrm{D}$-collagen matrices but not in liquid co-cultures (Xu et al., 2014). These results could be due to the different spatiotemporal organization of F-actin in the IS(DC) of the KO-Myo9B DCs under both conditions (Xu et al., 2014).

\section{RhoA, Rac1 and Rac 2}

RhoA, Rac1, and Rac 2 belong to the Rho GTPase subfamily, which are critical regulators of the actin cytoskeleton (see Figure 1, and Table 1 and legend) (Sit and Manser, 2011). Treatment of the DCs with epidermal cell differentiation inhibitor (EDIN) toxin, which inactivates RhoA, or inhibition of its downstream target, the Rho-associated protein kinase (ROCK), with Y27632, failed to affect IS formation between BM-DCs and OTII CD4 ${ }^{+}$TCs (Benvenuti et al., 2004). These results suggest that the effects of knocking down SWAP-70 on F-actin discussed above could be mediated by RhoB, instead of RhoA. DCs deficient in Rac1 and Rac2 show alterations in the F-actin organization, resulting in the absence of dendrites and reduced motility. In vitro analyses show that Rac1/2-KO BMDCs do not form stable contacts with $\mathrm{CD} 4{ }^{+}$TCs. Consistent with these results, the Rac1/2-KO BM-DCs show a reduced ability to activate OTII CD4 ${ }^{+}$TCs. It was suggested that this inhibition was due to deficient actin dynamics in the Rac1/2-KO DCs that prevent these cells from engulfing and establishing full contacts with TCs (Benvenuti et al., 2004).

\section{Cytohesin-Interacting Protein (CYTIP)}

Although CYTIP is not an actin-regulatory protein, we have included it in this review because it regulates LFA-1, which is an important molecule at the IS(DC) (Figure 1). In resting DCs, LFA-1 remains on the plasma membrane in an inactive state; that is, it cannot bind to its ligand ICAM-1. DCs express cytohesin-1, which interacts with the cytoplasmic $\beta$-subunit of LFA-1, resulting in its activation and binding to ICAM-1. CYTIP binds to cytohesin-1, which translocates from the membrane to the cytoplasm, leaving LFA-1 inactivated. During DC maturation, CYTIP levels increase and localize to the IS(DC) (Hofer et al., 2006). Studies on CYTIP in DCs are controversial (Table 1). In experiments in which CYTIP was reduced with siRNA in human DCs (Hofer et al., 2006), these cells showed a diminished ability to induce proliferation of autologous antigen-specific CD8 $^{+}$TCs (Hofer et al., 2006). Other studies show that knocking down CYTIP with siRNA in BM-DCs extends antigen-specific contacts with OTII CD4 ${ }^{+}$TCs or OTI CD8 ${ }^{+}$TCs and reduces the activation and proliferation of these cells (Balkow et al., 2010). In contrast, in experiments performed with DCs obtained from CYTIP KO mice (Coppola et al., 2006), CYTIP KO BMDCs enhanced antigen-specific activation OTI and OTII TCs (Heib et al., 2012).

\section{CONCLUDING REMARKS}

The study of the role of F-actin at the IS(DCs) is at its inception. The data discussed above suggest that F-actin polarization at the IS(DC) maintain IS stability necessary to induce TC activation. A network of actin-regulatory proteins controls F-actin organization at the IS(DC) (Figure 1). The pharmacological disruption of F-actin, the knockdown of Rac1/2, or the increase of F-actin levels after knocking down Myo9b reduce the ability of the DCs to activate the TCs. Knockdown of WASP or WRC, which promotes branched actin through Arp2/3, or mDia, which regulates linear F-actin, or fascin, a bundling protein, results in inhibition of TC activation. Deletion of WASP, mDia, fascin, and Rac1/2 reduces the number and/or the duration of DC-TC contacts. In contrast, knockdown of WRC or Myo9b results in extended DC-TC contacts and inhibition of TC activation. In summary, perturbation of F-actin dynamics at the IS(DC) leads to the inhibition of TC activation. Multiple 
aspects of the F-actin regulation and functions at the IS(DC) need to be addressed in the future. For this purpose, it is very important to develop experimental strategies that selectively target F-actin and its regulatory proteins at the IS(DC). Many wonderful things remain to be discovered at the IS(DC).

\section{AUTHOR CONTRIBUTIONS}

JR-F designed the work and wrote the manuscript with the help of OC-G. OC-G prepared the table and the figure. Both authors

\section{REFERENCES}

Al-Alwan, M. M., Liwski, R. S., Haeryfar, S. M., Baldridge, W. H., Hoskin, D. W., Rowden, G., et al. (2003). Cutting edge: dendritic cell actin cytoskeletal polarization during immunological synapse formation is highly antigendependent. J. Immunol. 171, 4479-4483. doi: 10.4049/jimmunol.171.9.4479

Al-Alwan, M. M., Rowden, G., Lee, T. D., and West, K. A. (2001b). The dendritic cell cytoskeleton is critical for the formation of the immunological synapse. J. Immunol. 166, 1452-1456. doi: 10.4049/jimmunol.166.3.1452

Al-Alwan, M. M., Rowden, G., Lee, T. D., and West, K. A. (2001a). Fascin is involved in the antigen presentation activity of mature dendritic cells. J. Immunol. 166, 338-345. doi: 10.4049/jimmunol.166.1.338

Alcaraz-Serna, A., Bustos-Moran, E., Fernandez-Delgado, I., Calzada-Fraile, D., Torralba, D., Marina-Zarate, E., et al. (2021). Immune synapse instructs epigenomic and transcriptomic functional reprogramming in dendritic cells. Sci. Adv. 7:eabb9965.

Bajenoff, M., Granjeaud, S., and Guerder, S. (2003). The strategy of T cell antigenpresenting cell encounter in antigen-draining lymph nodes revealed by imaging of initial T cell activation. J. Exp. Med. 198, 715-724. doi: 10.1084/jem.20030167

Balkow, S., Heinz, S., Schmidbauer, P., Kolanus, W., Holzmann, B., Grabbe, S., et al. (2010). LFA-1 activity state on dendritic cells regulates contact duration with $\mathrm{T}$ cells and promotes T-cell priming. Blood 116, 1885-1894. doi: 10.1182/blood2009-05-224428

Banchereau, J., and Steinman, R. M. (1998). Dendritic cells and the control of immunity. Nature 392, 245-252. doi: 10.1038/32588

Benvenuti, F. (2016). The dendritic cell synapse: a life dedicated to T cell activation. Front. Immunol. 7:70. doi: 10.3389/fimmu.2016.00070

Benvenuti, F., Hugues, S., Walmsley, M., Ruf, S., Fetler, L., Popoff, M., et al. (2004). Requirement of Rac1 and Rac2 expression by mature dendritic cells for $\mathrm{T}$ cell priming. Science 305, 1150-1153. doi: 10.1126/science.1099159

Blander, J. M., and Medzhitov, R. (2006). Toll-dependent selection of microbial antigens for presentation by dendritic cells. Nature 440, 808-812. doi: 10.1038/ nature 04596

Bouma, G., Mendoza-Naranjo, A., Blundell, M. P., de Falco, E., Parsley, K. L., Burns, S. O., et al. (2011). Cytoskeletal remodeling mediated by WASp in dendritic cells is necessary for normal immune synapse formation and T-cell priming. Blood 118, 2492-2501. doi: 10.1182/blood-2011-03-340265

Bousso, P., and Robey, E. (2003). Dynamics of CD8+ T cell priming by dendritic cells in intact lymph nodes. Nat. Immunol. 4, 579-585. doi: 10.1038/ni928

Bretou, M., Kumari, A., Malbec, O., Moreau, H. D., Obino, D., Pierobon, P., et al. (2016). Dynamics of the membrane-cytoskeleton interface in MHC class IIrestricted antigen presentation. Immunol. Rev. 272, 39-51. doi: 10.1111/imr. 12429

Brossard, C., Feuillet, V., Schmitt, A., Randriamampita, C., Romao, M., Raposo, G., et al. (2005). Multifocal structure of the T cell - dendritic cell synapse. Eur. J. Immunol. 35, 1741-1753. doi: 10.1002/eji.200425857

Buracco, S., Claydon, S., and Insall, R. (2019). Control of actin dynamics during cell motility. F1000 Res. 8:F1000 Faculty Rev-1977.

Celli, S., Lemaitre, F., and Bousso, P. (2007). Real-time manipulation of T celldendritic cell interactions in vivo reveals the importance of prolonged contacts for CD4+ T cell activation. Immunity 27, 625-634. doi: 10.1016/j.immuni.2007. 08.018 contributed to manuscript revision, and read and approved the submitted version.

\section{FUNDING}

JR-F was supported by grants awarded by Ministerio de Economía y Competitividad (SAF2014-53151-R, SAF201783306-R, and 2020AEP158 Ayuda Extra.2020TEC2017-85059C3-3-R), RIER (RETICS Program/Instituto de Salud Carlos III) (RD08/0075), and Consejería de Educación y Empleo from Comunidad de Madrid (Raphyme, S2010/BMD-2350).

Chacon-Martinez, C. A., Kiessling, N., Winterhoff, M., Faix, J., Muller-Reichert, T., and Jessberger, R. (2013). The switch-associated protein 70 (SWAP70) bundles actin filaments and contributes to the regulation of F-actin dynamics. J. Biol. Chem. 288, 28687-28703. doi: 10.1074/jbc.m113.461 277

Comrie, W. A., Li, S., Boyle, S., and Burkhardt, J. K. (2015). The dendritic cell cytoskeleton promotes $\mathrm{T}$ cell adhesion and activation by constraining ICAM-1 mobility. J. Cell Biol. 208, 457-473. doi: 10.1083/jcb.201406120

Coppola, V., Barrick, C. A., Bobisse, S., Rodriguez-Galan, M. C., Pivetta, M., Reynolds, D., et al. (2006). The scaffold protein Cybr is required for cytokinemodulated trafficking of leukocytes in vivo. Mol. Cell Biol. 26, 5249-5258. doi: $10.1128 / \mathrm{mcb} .02473-05$

Coupel, S., Leboeuf, F., Boulday, G., Soulillou, J. P., and Charreau, B. (2004). RhoA activation mediates phosphatidylinositol 3-kinase-dependent proliferation of human vascular endothelial cells: an alloimmune mechanism of chronic allograft nephropathy. J. Am. Soc. Nephrol. 15, 2429-2439. doi: 10.1097/01.asn. 0000138237.42675 .45

Dehring, D. A., Clarke, F., Ricart, B. G., Huang, Y., Gomez, T. S., Williamson, E. K., et al. (2011). Hematopoietic lineage cell-specific protein 1 functions in concert with the Wiskott-Aldrich syndrome protein to promote podosome array organization and chemotaxis in dendritic cells. J. Immunol. 186, 48054818. doi: 10.4049/jimmunol.1003102

Delon, J., Bercovici, N., Raposo, G., Liblau, R., and Trautmann, A. (1998). Antigendependent and -independent $\mathrm{Ca} 2+$ responses triggered in $\mathrm{T}$ cells by dendritic cells compared with B cells. J. Exp. Med. 188, 1473-1484. doi: 10.1084/jem.188. 8.1473

Eun, S. Y., O'Connor, B. P., Wong, A. W., van Deventer, H. W., Taxman, D. J., Reed, W., et al. (2006). Cutting edge: rho activation and actin polarization are dependent on plexin-A1 in dendritic cells. J. Immunol. 177, 4271-4275. doi: 10.4049/jimmunol.177.7.4271

Feigelson, S. W., Pasvolsky, R., Cemerski, S., Shulman, Z., Grabovsky, V., Ilani, T., et al. (2010). Occupancy of lymphocyte LFA-1 by surface-immobilized ICAM1 is critical for TCR- but not for chemokine-triggered LFA-1 conversion to an open headpiece high-affinity state. J. Immunol. 185, 7394-7404. doi: 10.4049/ jimmunol.1002246

Fenteany, G., and Zhu, S. (2003). Small-molecule inhibitors of actin dynamics and cell motility. Curr. Top. Med. Chem. 3, 593-616. doi: 10.2174/ 1568026033452348

Fisher, P. J., Bulur, P. A., Vuk-Pavlovic, S., Prendergast, F. G., and Dietz, A. B. (2008). Dendritic cell microvilli: a novel membrane structure associated with the multifocal synapse and T-cell clustering. Blood 112, 5037-5045. doi: 10. 1182/blood-2008-04-149526

Freiberg, B. A., Kupfer, H., Maslanik, W., Delli, J., Kappler, J., Zaller, D. M., et al. (2002). Staging and resetting T cell activation in SMACs. Nat. Immunol. 3, 911-917. doi: 10.1038/ni836

Gomez-Cabanas, L., Lopez-Cotarelo, P., Criado-Garcia, O., Murphy, M. P., Boya, P., and Rodriguez-Fernandez, J. L. (2019). Immunological synapse formation induces mitochondrial clustering and mitophagy in dendritic cells. J. Immunol. 202, 1715-1723. doi: 10.4049/jimmunol.1800575

Gomez-Cambronero, J. (2012). Structure analysis between the SWAP-70 RHOGEF and the newly described PLD2-GEF. Small GTPases 3, 202-208. doi: $10.4161 /$ sgtp. 20887 
Grakoui, A., Bromley, S. K., Sumen, C., Davis, M. M., Shaw, A. S., Allen, P. M., et al. (1999). The immunological synapse: a molecular machine controlling $\mathrm{T}$ cell activation. Science 285, 221-227. doi: 10.1126/science.285.5425.221

Hanley, P. J., Xu, Y., Kronlage, M., Grobe, K., Schon, P., Song, J., et al. (2010). Motorized RhoGAP myosin IXb (Myo9b) controls cell shape and motility. Proc. Natl. Acad. Sci. U. S. A. 107, 12145-12150. doi: 10.1073/pnas.0911986107

Hao, J. J., Zhu, J., Zhou, K., Smith, N., and Zhan, X. (2005). The coiled-coil domain is required for HS1 to bind to F-actin and activate Arp2/3 complex. J. Biol. Chem. 280, 37988-37994. doi: 10.1074/jbc.m504552200

Heib, V., Sparber, F., Tripp, C. H., Ortner, D., Stoitzner, P., and Heufler, C. (2012). Cytip regulates dendritic-cell function in contact hypersensitivity. Eur. J. Immunol. 42, 589-597. doi: 10.1002/eji.201041286

Hofer, S., Pfeil, K., Niederegger, H., Ebner, S., Nguyen, V. A., Kremmer, E., et al. (2006). Dendritic cells regulate T-cell deattachment through the integrininteracting protein CYTIP. Blood 107, 1003-1009. doi: 10.1182/blood-200501-0425

Huang, Y., Biswas, C., Klos Dehring, D. A., Sriram, U., Williamson, E. K., Li, S., et al. (2011). The actin regulatory protein HS1 is required for antigen uptake and presentation by dendritic cells. J. Immunol. 187, 5952-5963. doi: 10.4049/ jimmunol.1100870

Iezzi, G., Karjalainen, K., and Lanzavecchia, A. (1998). The duration of antigenic stimulation determines the fate of naive and effector T cells. Immunity 8, 89-95. doi: 10.1016/s1074-7613(00)80461-6

Jin, Y. P., Korin, Y., Zhang, X., Jindra, P. T., Rozengurt, E., and Reed, E. F. (2007). RNA interference elucidates the role of focal adhesion kinase in HLA class I-mediated focal adhesion complex formation and proliferation in human endothelial cells. J. Immunol. 178, 7911-7922. doi: 10.4049/jimmunol.178.12. 7911

Leithner, A., Altenburger, L. M., Hauschild, R., Assen, F. P., Rottner, K., Stradal, T. E. B., et al. (2021). Dendritic cell actin dynamics control contact duration and priming efficiency at the immunological synapse. J. Cell Biol. 220:e20200 6081 .

Lepin, E. J., Jin, Y. P., Barwe, S. P., Rozengurt, E., and Reed, E. F. (2004). HLA class I signal transduction is dependent on Rho GTPase and ROK. Biochem. Biophys. Res. Commun. 323, 213-217. doi: 10.1016/j.bbrc.2004.08.082

Malinova, D., Fritzsche, M., Nowosad, C. R., Armer, H., Munro, P. M., Blundell, M. P., et al. (2016). WASp-dependent actin cytoskeleton stability at the dendritic cell immunological synapse is required for extensive, functional $\mathrm{T}$ cell contacts. J. Leukoc. Biol. 99, 699-710. doi: 10.1189/jlb.2a0215-050rr

Mempel, T. R., Henrickson, S. E., and Von Andrian, U. H. (2004). T-cell priming by dendritic cells in lymph nodes occurs in three distinct phases. Nature 427, 154-159. doi: 10.1038/nature02238

Merad, M., Sathe, P., Helft, J., Miller, J., and Mortha, A. (2013). The dendritic cell lineage: ontogeny and function of dendritic cells and their subsets in the steady state and the inflamed setting. Annu. Rev. Immunol. 31, 563-604. doi: 10.1146/annurev-immunol-020711-074950

Miller, M. J., Safrina, O., Parker, I., and Cahalan, M. D. (2004). Imaging the single cell dynamics of CD4+ T cell activation by dendritic cells in lymph nodes. J. Exp. Med. 200, 847-856. doi: 10.1084/jem.20041236

Monks, C. R., Freiberg, B. A., Kupfer, H., Sciaky, N., and Kupfer, A. (1998). Threedimensional segregation of supramolecular activation clusters in T cells. Nature 395, 82-86. doi: 10.1038/25764

Mosialos, G., Birkenbach, M., Ayehunie, S., Matsumura, F., Pinkus, G. S., Kieff, E., et al. (1996). Circulating human dendritic cells differentially express high levels of a 55-kd actin-bundling protein. Am. J. Pathol. 148, 593-600.

Mossman, K. D., Campi, G., Groves, J. T., and Dustin, M. L. (2005). Altered TCR signaling from geometrically repatterned immunological synapses. Science 310, 1191-1193. doi: 10.1126/science. 1119238

Ocana-Morgner, C., Wahren, C., and Jessberger, R. (2009). SWAP-70 regulates RhoA/RhoB-dependent MHCII surface localization in dendritic cells. Blood 113, 1474-1482. doi: 10.1182/blood-2008-04-152587

Park, H., Staehling-Hampton, K., Appleby, M. W., Brunkow, M. E., Habib, T., Zhang, Y., et al. (2008). A point mutation in the murine Heml gene reveals an essential role for Hematopoietic protein 1 in lymphopoiesis and innate immunity. J. Exp. Med. 205, 2899-2913. doi: 10.1084/jem.20080340

Pulecio, J., Tagliani, E., Scholer, A., Prete, F., Fetler, L., Burrone, O. R., et al. (2008). Expression of Wiskott-Aldrich syndrome protein in dendritic cells regulates synapse formation and activation of naive CD8+ T cells. J. Immunol. 181, 1135-1142. doi: 10.4049/jimmunol.181.2.1135

Regnault, A., Lankar, D., Lacabanne, V., Rodriguez, A., Thery, C., Rescigno, M., et al. (1999). Fcgamma receptor-mediated induction of dendritic cell maturation and major histocompatibility complex class I-restricted antigen presentation after immune complex internalization. J. Exp. Med. 189, 371-380. doi: 10.1084/jem.189.2.371

Reichardt, P., Dornbach, B., Rong, S., Beissert, S., Gueler, F., Loser, K., et al. (2007). Naive B cells generate regulatory T cells in the presence of a mature immunologic synapse. Blood 110, 1519-1529. doi: 10.1182/blood-2006-10053793

Riedl, J., Crevenna, A. H., Kessenbrock, K., Yu, J. H., Neukirchen, D., Bista, M., et al. (2008). Lifeact: a versatile marker to visualize F-actin. Nat. Methods 5, 605-607. doi: 10.1038/nmeth.1220

Riol-Blanco, L., Delgado-Martin, C., Sanchez-Sanchez, N., Alonso, C. L., GutierrezLopez, M. D., Del Hoyo, G. M., et al. (2009). Immunological synapse formation inhibits, via NF-kappaB and FOXO1, the apoptosis of dendritic cells. Nat. Immunol. 10, 753-760. doi: 10.1038/ni.1750

Rodriguez-Fernandez, J. L., Riol-Blanco, L., and Delgado-Martin, C. (2010b). What is the function of the dendritic cell side of the immunological synapse? Sci. Signal. 3:re2. doi: 10.1126/scisignal.3105re2

Rodriguez-Fernandez, J. L., Riol-Blanco, L., and Delgado-Martin, C. (2010a). What is an immunological synapse? Microbes Infect. 12, 438-445.

Rothoeft, T., Balkow, S., Krummen, M., Beissert, S., Varga, G., Loser, K., et al. (2006). Structure and duration of contact between dendritic cells and T cells are controlled by $\mathrm{T}$ cell activation state. Eur. J. Immunol. 36, 3105-3117. doi: 10.1002/eji.200636145

Scholer, A., Hugues, S., Boissonnas, A., Fetler, L., and Amigorena, S. (2008). Intercellular adhesion molecule-1-dependent stable interactions between $\mathrm{T}$ cells and dendritic cells determine CD8+ T cell memory. Immunity 28, 258-270. doi: 10.1016/j.immuni.2007.12.016

Schonichen, A., and Geyer, M. (2010). Fifteen formins for an actin filament: a molecular view on the regulation of human formins. Biochim. Biophys. Acta 1803, 152-163. doi: 10.1016/j.bbamcr.2010.01.014

Shakhar, G., Lindquist, R. L., Skokos, D., Dudziak, D., Huang, J. H., Nussenzweig, M. C., et al. (2005). Stable T cell-dendritic cell interactions precede the development of both tolerance and immunity in vivo. Nat. Immunol. 6, 707714. doi: $10.1038 /$ ni1210

Shen, K., Thomas, V. K., Dustin, M. L., and Kam, L. C. (2008). Micropatterning of costimulatory ligands enhances CD4+ T cell function. Proc. Natl. Acad. Sci. U. S. A. 105, 7791-7796. doi: 10.1073/pnas.0710295105

Sit, S.-T., and Manser, E. (2011). Rho GTPases and their role in organizing the actin cytoskeleton. J. Cell Sci. 124(Pt 5), 679-683. doi: 10.1242/jcs.064964

Stoll, S., Delon, J., Brotz, T. M., and Germain, R. N. (2002). Dynamic imaging of T cell-dendritic cell interactions in lymph nodes. Science 296, 1873-1876. doi: 10.1126/science.1071065

Tanizaki, H., Egawa, G., Inaba, K., Honda, T., Nakajima, S., Moniaga, C. S., et al. (2010). Rho-mDial pathway is required for adhesion, migration, and T-cell stimulation in dendritic cells. Blood 116, 5875-5884. doi: 10.1182/blood-201001-264150

Thauland, T. J., and Parker, D. C. (2010). Diversity in immunological synapse structure. Immunology 131, 466-472. doi: 10.1111/j.1365-2567.2010.03366.x

Tseng, S. Y., Waite, J. C., Liu, M., Vardhana, S., and Dustin, M. L. (2008). T celldendritic cell immunological synapses contain TCR-dependent CD28-CD80 clusters that recruit protein kinase C theta. J. Immunol. 181, 4852-4863. doi: 10.4049/jimmunol.181.7.4852

Uruno, T., Zhang, P., Liu, J., Hao, J. J., and Zhan, X. (2003). Haematopoietic lineage cell-specific protein 1 (HS1) promotes actin-related protein (Arp) 2/3 complex-mediated actin polymerization. Biochem. J. 371(Pt 2), 485-493. doi: 10.1042/bj20021791

Verboogen, D. R., Dingjan, I., Revelo, N. H., Visser, L. J., ter Beest, M., and van den Bogaart, G. (2016). The dendritic cell side of the immunological synapse. Biomol. Concepts 7, 17-28. doi: 10.1515/bmc-2015-0028

Weaver, A. M., Karginov, A. V., Kinley, A. W., Weed, S. A., Li, Y., Parsons, J. T., et al. (2001). Cortactin promotes and stabilizes Arp2/3-induced actin filament network formation. Curr. Biol. 11, 370-374. doi: 10.1016/s0960-9822(01) 00098-7 
Xu, Y., Pektor, S., Balkow, S., Hemkemeyer, S. A., Liu, Z., Grobe, K., et al. (2014). Dendritic cell motility and $\mathrm{T}$ cell activation requires regulation of Rho-cofilin signaling by the Rho-GTPase activating protein myosin IXb. J. Immunol. 192, 3559-3568. doi: 10.4049/jimmunol.1300695

Yamashiro, S. (2012). Functions of fascin in dendritic cells. Crit. Rev. Immunol. 32, 11-21. doi: 10.1615/critrevimmunol.v32. i1.20

Ziegler, M. E., Jin, Y. P., Young, S. H., Rozengurt, E., and Reed, E. F. (2012a). HLA class I-mediated stress fiber formation requires ERK1/2 activation in the absence of an increase in intracellular $\mathrm{Ca} 2+$ in human aortic endothelial cells. Am. J. Physiol. Cell Physiol. 303, C872-C882.

Ziegler, M. E., Souda, P., Jin, Y. P., Whitelegge, J. P., and Reed, E. F. (2012b). Characterization of the endothelial cell cytoskeleton following HLA class I ligation. PLoS One 7:e29472. doi: 10.1371/journal.pone.0029 472
Conflict of Interest: The authors declare that the research was conducted in the absence of any commercial or financial relationships that could be construed as a potential conflict of interest.

Publisher's Note: All claims expressed in this article are solely those of the authors and do not necessarily represent those of their affiliated organizations, or those of the publisher, the editors and the reviewers. Any product that may be evaluated in this article, or claim that may be made by its manufacturer, is not guaranteed or endorsed by the publisher.

Copyright $\odot 2021$ Rodríguez-Fernández and Criado-García. This is an open-access article distributed under the terms of the Creative Commons Attribution License (CC BY). The use, distribution or reproduction in other forums is permitted, provided the original author(s) and the copyright owner(s) are credited and that the original publication in this journal is cited, in accordance with accepted academic practice. No use, distribution or reproduction is permitted which does not comply with these terms. 